\title{
DEVELOPMENT OF GROUNDWATER FLOW MODEL (MODFLOW) TO SIMULATE THE ESCALATING GROUNDWATER PUMPING IN THE PUNJAB, PAKISTAN
}

\author{
Aamir Shakoor ${ }^{1, *}$, Muhammad Arshad ${ }^{2}$, Riaz Ahmad $^{3}$, Zahid Mahmood Khan', Uzair Qamar $^{2}$, \\ H. Umar Farid ${ }^{1}$, Muhammad Sultan ${ }^{1,4}$ and Fiaz Ahmad ${ }^{1}$
}

\author{
${ }^{1}$ Department of Agricultural Engineering, Bahauddin Zakariya University, Multan, Pakistan; ${ }^{2}$ Department of \\ Irrigation and Drainage, University of Agriculture, Faisalabad, Pakistan; ${ }^{3}$ Department of Agronomy, University of \\ Agriculture, Faisalabad, Pakistan; ${ }^{4}$ International Institute for Carbon-Neutral Energy Research (WPI-I2CNER), \\ Kyushu University, Japan. \\ "Corresponding author's e-mail: aamirskr@yahoo.com
}

\begin{abstract}
The application of groundwater resources in Punjab, Pakistan to meet the crop water requirements is increasing rapidly due to constrained surface water supplies. However, the abundant abstraction of groundwater has created serious negative concerns in terms of lowering water table. Thus the sustainability of regional groundwater resources depends upon its proficient management through groundwater modeling technique. Therefore, a research was accomplished to quantify the groundwater pumping and to identify the groundwater depletion areas using MODFLOW model. Three pumping scenarios were developed up to year 2030: such as Scenario-I (Maintaining the current pumping rate for the study period); Scenario-II (Increase in pumping rate according to the historical trend); and Scenario-III (Adjusted canal water supplies and groundwater patterns). The results of Scenario-I indicated that the groundwater level would decline up to $14 \mathrm{~m}$ for the study period. Scenario-II results showed maximum decline of groundwater level, which would be $18 \mathrm{~m}$ up to year 2030 . The adjusted canal and groundwater supplies among upper and middle part of the study area in Scenario-III, which will recover the groundwater by $2-3 \mathrm{~m}$ in the middle part of the study area, gave a good management strategy. So, in lower and middle part of study area, groundwater should be artificially recharged and more canal should be supplied water to avoid depletion.

Keywords: Groundwater, modeling, groundwater level, groundwater management, management scenarios
\end{abstract}

\section{INTRODUCTION}

In view of the constrained canal water supplies, groundwater plays a pivotal role in the development of irrigated agricultural productivity. Annually, 750-800 billion cubic meters (BCM) of global groundwater withdrawals are being used for agriculture (Shah, 2014; Shakoor et al., 2015). Like many other countries of the world, Pakistan depends heavily on irrigated agriculture because of the arid climatic conditions. The rainfall is spatially varied from $150 \mathrm{~mm}$ in the Southern to more than $750 \mathrm{~mm}$ in the Northern West part of the country (Ghani et al., 2013; Shakoor et al., 2012) against the average evapotranspiration of $1778 \mathrm{~mm}$ (Shabbir et al., 2012). This imbalance between the rainfall and crop water requirements necessitates the application of irrigation water to grow crops successfully around the year.

The Indus Basin Irrigation System (IBIS) of Pakistan is supplying good quality irrigation water to the irrigated lands through a well-developed canal network. However, due to a number of system inefficiencies and high degree of conveyance and application water losses, the system operates at less than $40 \%$ efficiency that meets only less than $40 \%$ of the crop water requirements (Arshad et al., 2013). Thus, provision of irrigation water from other sources such as groundwater is indispensable for potential productivity (Bhutta and Smedema, 2007).

Therefore, the growth rate of private tubewells has increased at the rate of 60\% in Punjab from 1991 to 2000. Currently, more than 1.2 million private tubewells of small capacity have been installed in Pakistan, out of which $86 \%$ are only in Punjab province (Shakoor et al., 2015). Similarly, the area irrigated from tubewells in Punjab was 10.99Mha in 2010-11, increased at the rate of $7.85 \%$ in ten years (PES, 2011). This clearly indicates that without groundwater availability, not only Punjab but the whole country would face food shortages as Punjab produces more than $90 \%$ of the total grains. Similarly, about $90 \%$ of the population in Punjab-Pakistan is using groundwater to fulfill their domestic needs (Qureshi et al., 2010).

Due to this intensive pumping of groundwater in Pakistan, water table is falling at a rate of $2-3 \mathrm{~m}$ annually. As a result, 15 and 5\% irrigated areas of Balochistan and Punjab provinces, respectively were unreachable to pump water economically (Qureshi et al., 2010). If this situation continues, the domestic and irrigation pumps would not be able to lift water at their present pumping location. This 
overexploitation of groundwater has introduced the management problem of groundwater (Watto and Mugera, 2016; Shakoor et al., 2015). There are several techniques are available to manage groundwater resources but among them groundwater modeling is the best choice and the model is a simplified version of the real system (Adane, 2014). Several regional groundwater modeling studies have been accomplished in different part of world (Moeck et al., 2017; Gebreyohannes et al., 2017; Asoka et al., 2017; Galitskaya et al., 2017; Kambale et al., 2017; Abdullah and Morteza, 2017; Durand et al., 2017; Carretero et al., 2013; Moon et al., 2010; Abu-el-Shar and Hatamleh, 2007). They used different models for groundwater management and emphasized that the model techniques could be helpful for management of the groundwater resources (Kori et al., 2013). The most of the investigations about of groundwater modeling in world were carried out by MODFLOW model (Rahmawati et al., 2013; Kori et al., 2013; Lalehzari et al., 2010).

Therefore, development of indigenous groundwater model is necessary to find out possible solutions of the local groundwater management problem for its sustainability. If unchecked mining of aquifer water remains continue in the study area, the irrigation tubewells would not be able to lift water at their present level. Hence, there is a dire need to investigate the impact of groundwater flow conditions and overexploitation on groundwater quantity. Thus, the followings were the two main objectives of the current study 1) To simulate and calibrate regional groundwater flow model and observe its future watertable trend and 2) To develop groundwater management scenarios for its better sustainability.

\section{MATERIALS AND METHODS}

Study area: The research was carried out in the command area of Lower Chenab Canal (LCC) West, Punjab province of Pakistan, located at $73^{\circ} 50^{\prime} 43^{\prime \prime E}$ to $72^{\circ} 10^{\prime} 50^{\prime \prime E}$ longitude and $32^{\circ} 18^{\prime} 56^{\prime \prime} \mathrm{N}$ to $30^{\circ} 50^{\prime} 42^{\prime \prime} \mathrm{N}$ latitude (Fig. 1). The gross and cultureable command area of the site are 1.1576 and $0.976 \mathrm{Mha}$, respectively. There are two main cropping seasons, Kharif (summer) and Rabi (winter). Rice, cotton and forage are main crops in Kharif while, wheat and forage are major crops of Rabi. In some regions, sugarcane is also cultivated as an annual crop. Study area is comprised of vast canal network from main canals to distributaries and minor. The River Chenab and Gugera Branch Canals are located on the Northwest and Southeast side whereas, Qadirabad-Baluki and Trimmu-Sidhnai Link canals on northeast and southwest sides (Fig. 2).

Climate: The climate data of study area for the years 2003 to 2012 were collected from Pakistan Meteorological Department, Lahore-Pakistan. The climate of study area has wide seasonal variations in temperature. The summer starts from April and continue till October with temperature varies between $21-51^{\circ} \mathrm{C}$. The winter season lasting October to April with temperature ranges between $7-27^{\circ} \mathrm{C}$. There was wide range of variation in monthly rainfall among the stations. The average annual precipitation was $439 \mathrm{~mm}$. The reference evapotranspiration $\left(\mathrm{ET}_{\mathrm{o}}\right.$ ) was calculated using "CROPWAT 8.0" model based on FAO (1998). The ten years average value of $\mathrm{ET}_{\mathrm{o}}$ was $1413 \mathrm{~mm} /$ year.

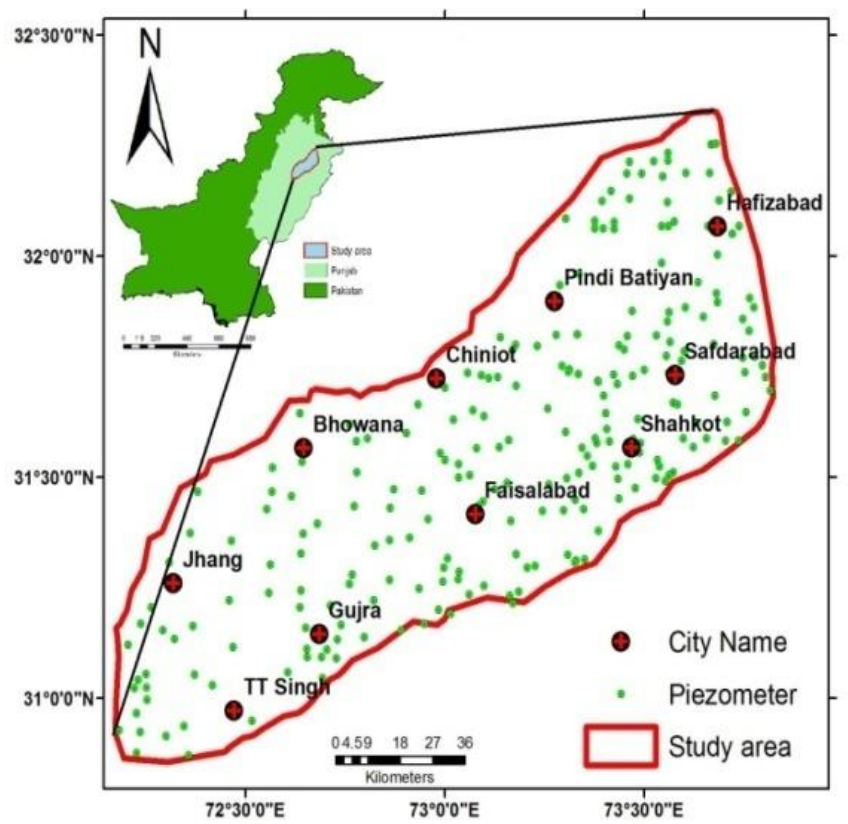

Figure 1. Geographic location of study area.

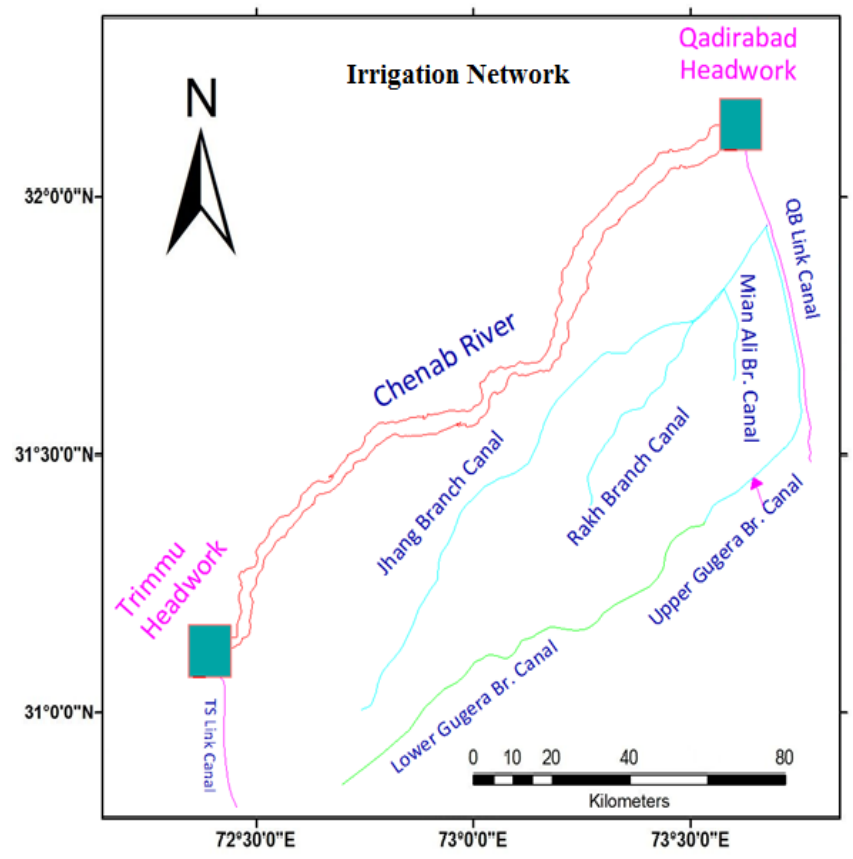

Figure 2. Canal system in the study area. 
Surface elevation: The surface elevation data were extracted using Global Mapper software, which is preferred software package as it is capable of reading large amounts of geospatial data in native format (Korzeniowska, 2012; Cliffen and Weeden, 2009). The higher elevation $(220 \mathrm{~m})$ was found in northeast side and comparative lower elevation $(160 \mathrm{~m})$ was found in southwest side of the study area, as shown in Fig. 3.

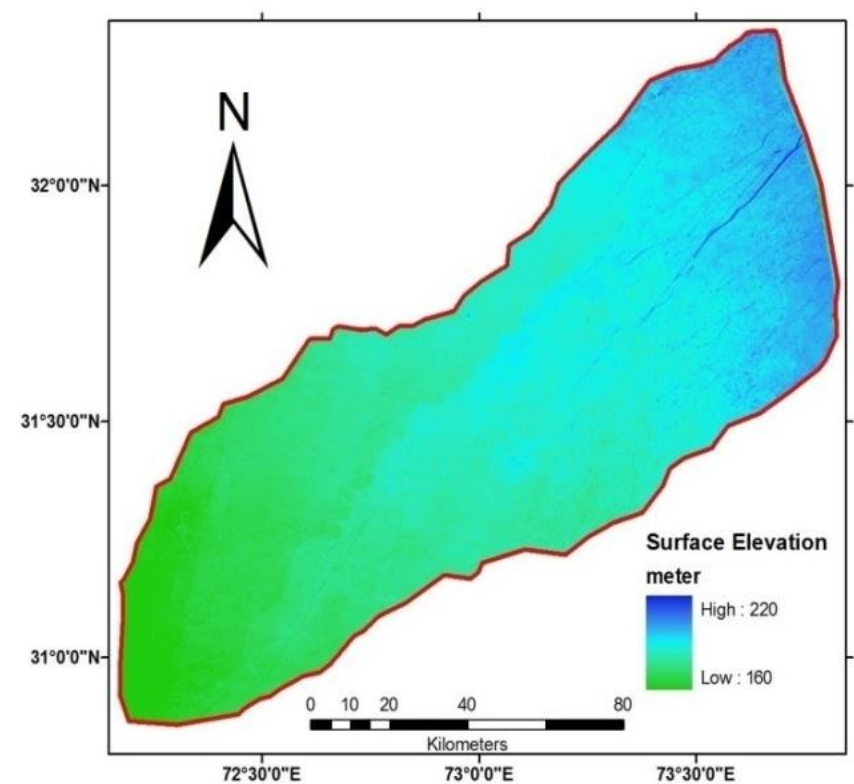

Figure 3. Surface elevation trend.

Lithology: The lithological data of 141 points, located in the study area, were collected from Water and Power Development Authority (WAPDA, 1978) and the location of boreholes is shown in the Figure 4. The analysis showed that the soil have different classification according to different textural characteristics. The surface soils textures are largely fine and moderately medium, with good permeability properties (Figure 5). The area consisted of $4451.3(38.48 \%)$, 4987.3 (43.08\%), 1621 (14\%) $464.1(4 \%)$ and $52.3 \mathrm{~km}^{2}$ $(0.45 \%)$ fine, moderately medium, medium, moderately course and course texture soil classes, respectively.

Groundwater data: The data of 256 piezometers regarding groundwater level were acquired from Irrigation Department, Faisalabad for the period from 2003 to 2012. The department take readings of groundwater level for pre-monsoon (June) and post-monsoon (October).

Development of MODFLOW model: MODFLOW is a simulation system, based on modular three-dimensional finite-difference technique for modeling groundwater flow and pollution. MODFLOW is one of the powerful groundwater modeling software, which is able to simulate groundwater flow in a wide range of natural systems. MODFLOW is used widely throughout the world and it can be applied to many modeling applications (Rahmawati et al.,
2013; Al-Fatlawi, 2011; Zailin et al., 2011; Abu-el-Shar and Hatamleh, 2007).

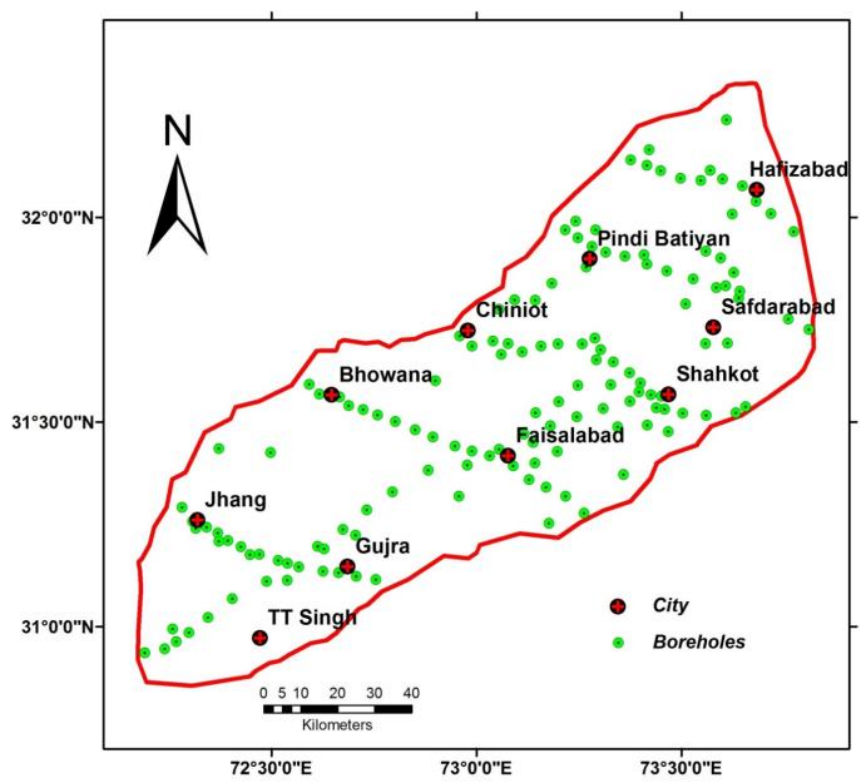

Figure 4. Location of borehole points of WAPDA.

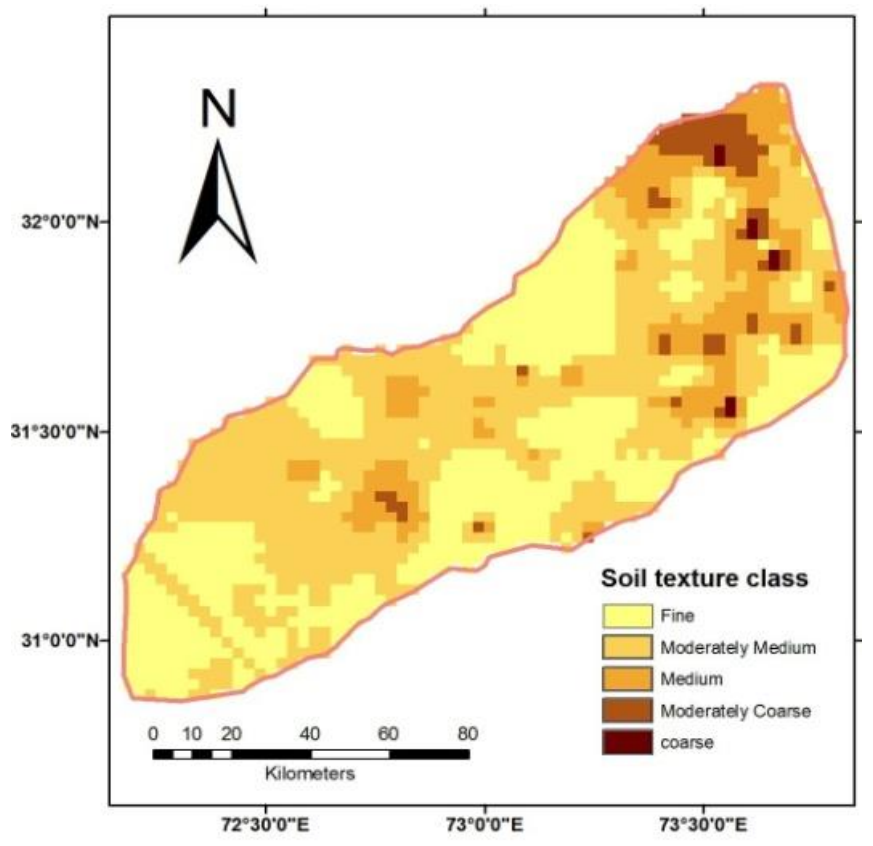

Figure 5. Surface soil texture class.

The groundwater model was developed using PMWIN 5.3 (Processing MODFLOW for Window) and Geographic Information System (GIS) software was used for input and out data preparation. PMWIN programs offer a totally integrated simulation system for modeling groundwater flow and transport processes with MODFLOW-88, MODFLOW-96, 
PMPATH, MT3D, MT3DMS, MOC3D, PEST and UCODE (Chiang and Kinzelbach, 1998). PMWIN is a simulation system based on the modular three-dimensional finitedifference technique for modeling groundwater flow and contamination in groundwater with a wide range of natural systems. In our study, the model area had a square geometry, which contained 5776 cells, in 76 columns and 76 rows. Each square cell has a dimension of $2500 \mathrm{~m} \times 2500 \mathrm{~m}$. The cell size of $2.5 \mathrm{~km} \times 2.5 \mathrm{~km}\left(6.25 \mathrm{~km}^{2}\right)$ was also used for groundwater modeling studies by Al-Fatlawi (2011) in Umm Er Radhuma, the Western Desert, Iraq and by Khan et al. (2008) in Rechna Doab. Abu-el-Shar and Hatamleh (2007) developed groundwater model for the Azraq Basin and the biggest cell size of $8.69 \mathrm{~km}^{2}$ was selected. Similarly, Schoups et al. (2005) used cell size of $2 \mathrm{~km} \times 2 \mathrm{~km}$ to calibrate groundwater model of the Yaqui Valley, having $6800 \mathrm{~km}^{2}$ irrigated agricultural region located along the Sea of Cortez in Sonora, Mexico. The model area had 3653 inactive cells, which were outside the boundary of the study area. While the model area had 2123 active cells located within the boundary of study area. The values of " 1 " and " 0 " were given to the active and inactive cells, respectively.

The aquifer of the study area was defined with four different layers depending upon their lithological data. The spatial domain represented in the model consisted of four layers (07, 7-30, 30-90 and 90m to bedrock) after Khan et al. (2008). The simulation time unit "days" and simulation flow type "transient" was selected. Two stress periods in each year were considered to represent the Kharif and Rabi seasons having 183 and 182 days, respectively with six time steps in each season/ stress period. Lithology of aquifer system in the study area was obtained from the Water and Power Development Authority WAPDA (1978). Based on the soil type the initial values of soil characteristics such as hydraulic conductivity, specific storage and specific yield were assessed from the CSIRO (2003). These values than varied within the range during the calibration process until the model was successful calibrated. The horizontal and vertical hydraulic conductivities have large variation from one to the other side of the study area. The minimum and maximum values used in the calibrated model for horizontal and vertical hydraulic conductivities were $1-265 \mathrm{~m} /$ day and $1-15 \mathrm{~m} /$ day, respectively. The similar range of values for hydraulic conductivity within Punjab province domain was used by Jehangir et al. (2002), Ahmad (2002) and Arshad (2004). The values of specific storage and specific yield used in the model were $0.0001-0.001 \mathrm{~m}^{-1}$ and $0.05-0.25$, respectively. The effective porosity of 0.25 was given to all the layers and used to calculate average velocity of the flow through porous medium after Wilkinson (2012), Gibb et al. (1984), WAPDA (1978) and McWhorter and Sunada (1977).

The cumulative evapotranspiration during a period (Kharif or Rabi) was divided by its duration in days and thus the evapotranspiration rate per day was calculated using
CROPWAT model. The model was based on the recommended FAO-56 (1998) method which is proven by many researches as the best available approach (Iyanda et al., 2014; Gohari, 2013; Al-Najar, 2011; Nazeer, 2009; Cavero et al., 2000). The evapotranspiration rate of 0.006 and $0.003 \mathrm{~m} /$ day were used to odd (Kharif) and even (Rabi) stress periods, respectively, throughout the model stress periods for model calibration. Kaleem-Ullah et al. (2001) determined the evapotranspiration in the Indus basin irrigation system of Pakistan and reported that the maximum evapotranspiration of different Rabi crops are about $462 \mathrm{~mm}$. whereas; Kharif crops have quite variable requirements up to $1004 \mathrm{~mm}$. The values used in model were in line with these values. The recharge package was used to simulate spatially distributed field recharge from rainfall and applied irrigation to the groundwater system. The estimation of recharge is complicated and involves a number of unknown factors, which made the estimation difficult. Sources of recharge to groundwater include infiltration from rainfall and losses from irrigated fields. Ahmad and Chaudhry (1988) conducted a field study to determine the recharge contribution to groundwater from rainfall and water delivered in irrigation fields in Upper Gogera Branch canal, Punjab, Pakistan. The contribution of recharge to groundwater was found from 17 to $22 \%$ of rainfall, while $20 \%$ was selected as used by Arshad et al. (2005), conducted a field and modeling study in Rechna Doab, Punjab, Pakistan. Approximately, $15 \%$ of water delivered to field assumed as recharge to groundwater based on the study by Ahmad and Chaudhry (1988). Hence, the minimum and maximum recharge values from 0.00065 to $0.0013 \mathrm{~m} /$ day were used for odd (Kharif) stress periods whereas, from 0.00026 to $0.0005 \mathrm{~m} /$ day for even (Rabi) stress periods. The higher value in odd stress periods was due to the high rainfall in those periods, high recharge to groundwater. The values entered in the model are in line with the research conducted by Arshad et al. (2005). They determined recharge rate using watertable fluctuation method at Upper Gogera Branch canal system, Punjab, Pakistan and found that the recharge contribution to groundwater from the rainfall and irrigated fields was at the rate of $0.000502 \mathrm{~m} / \mathrm{day}$, while the recharge from rainfall was $0.000225 \mathrm{~m} / \mathrm{day}$. The River package was used to simulate the flow between an aquifer and a surface water feature such as, rivers, canals, lakes and reservoirs. The hydraulic features, such as canal length, bed width, full supply level and discharge of the canals of the study area were used. The range of hydraulic conductance of the canals was from 9818 to $31494 \mathrm{~m}^{2} /$ day and from 6617 to $21337 \mathrm{~m}^{2} /$ day for odd and even stress periods, respectively. The recharge flux through canal system was computed by the model. The net groundwater demand was calculated by subtracting the net crop water requirement and net canal water supplies.

Future scenarios: Future prediction of groundwater head was done after the successful calibration and validation of the 
model. For this research the prediction was achieved regarding pumping rate up to year 2030, assuming that there will be no uncertain change or tragedy in the climatic conditions and in the irrigation system including Chenab River, for the following scenarios;

Scenario-I: maintaining the current pumping rate of 3759 MCM (million cubic meter) per year for the entire study period.

Scenario-II: Increase in pumping rate according to the historical trend. In Punjab, about 1 million tubewells are installed and are increasing at the rate of 5.5\% annually (PES, 2009).

Scenario-III: In the upper part of study area, the present rate of pumping is increased and irrigation recharge is decreased by $35 \%$. While in the middle part pumping is decreased and irrigation recharge is increased by same rate. In this scenario, one of the water management options for the study area was proposed. It was suggested that canal water supplies are shifted to the middle part of study area and groundwater abstraction is increased in the upper part (Pindi Bhatiyan Safdrabad) under current conditions at 2012.

\section{RESULTS AND DISCUSSION}

Calibration and validation of model: Model was calibrated with respect to observed groundwater level using inverse modeling method, the PEST (Doherty et al., 1994). PEST (parameter estimation) searches optimum parameter values for which the sum of squared deviations between modelcalculated and observed values of hydraulic heads or drawdowns at the observation boreholes is reduced to a minimum. In this iterative process, input parameters such as recharge, pumping rate and hydraulic conductivities were adjusted. Minimum and maximum values possible for the conceptual model were not exceeded in calibration of groundwater model. After providing the values of all parameters, the MODFLOW model was successfully calibrated and validated for the period of 2003-2012 (Fig. 6). The degree of fit between model simulations (calculated) and field measurements were quantified by statistical means (Table 1). The ME, MAE, RMSE, MEF and $\mathrm{R}^{2}$ were calculated and determined as $-1.10 \mathrm{~m}, 1.72 \mathrm{~m}, 2.24 \mathrm{~m}, 0.98$ and 0.89 , respectively. The minus sign of mean error indicated that the model simulated values were higher than the measured head. Moriasi et al. (2007) reported that RMSE, MAE, and MSE values of 0 indicate a perfect fit. Among these parameters, the RMSE is generally considered the best calibration indicator. Hagos (2010) calibrated MODFLOW model for Raya valley, Ethiopia with respect to groundwater level. The values of ME, MAE and RMSE of calibrated results were $-1.4 \mathrm{~m}, 7.8 \mathrm{~m}$ and $10.7 \mathrm{~m}$, respectively, with coefficient of determination of 0.97 and reported these results satisfactory.
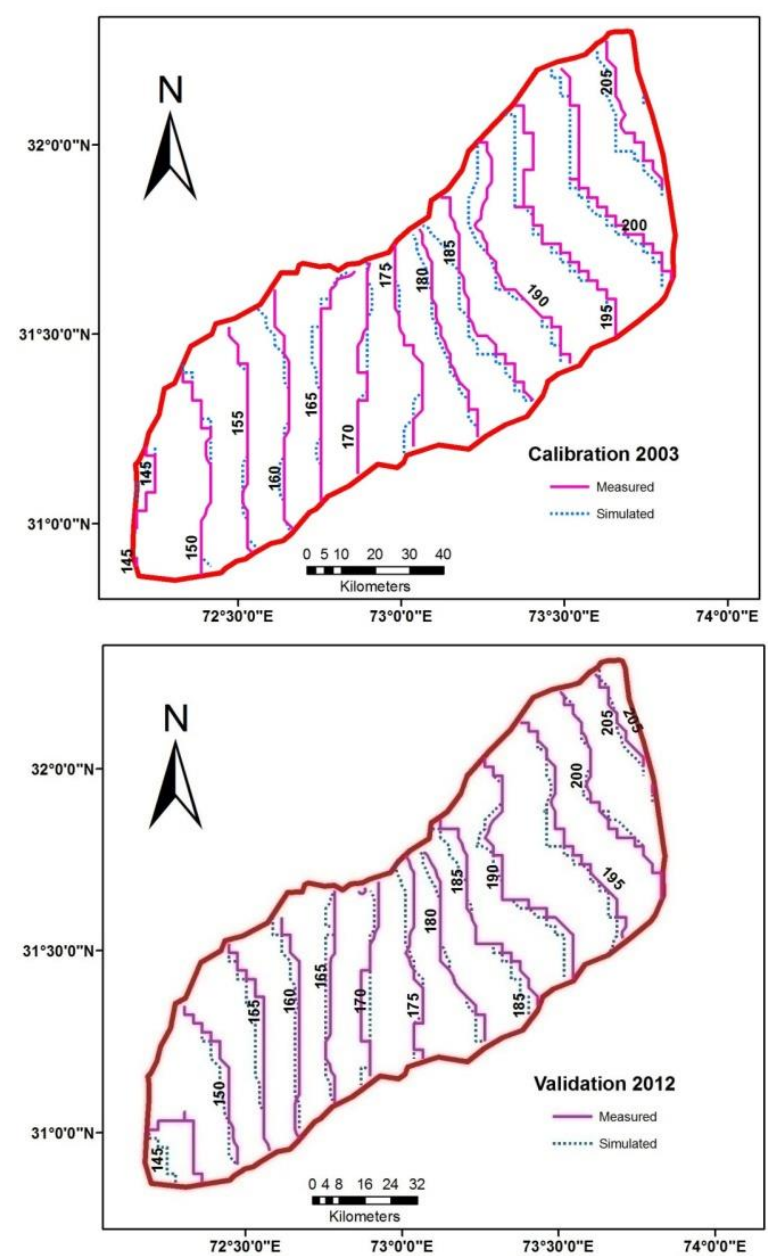

Figure 6. Model calibration and validation.

Table 1. Statistical analysis of the field and modeled data.

\begin{tabular}{llc}
\hline Parameters & Formula & Values \\
\hline Mean Error & $\mathrm{ME}=\frac{1}{n} \sum_{i=1}^{n}\left(h_{o}-h_{s}\right)$ & $-1.10 \mathrm{~m}$ \\
Mean Absolute & $\mathrm{MAE}=\frac{1}{n} \sum_{i=1}^{n}\left|h_{o}-h_{s}\right|$ & $1.72 \mathrm{~m}$ \\
$\begin{array}{l}\text { Error } \\
\text { Root Mean Square }\end{array}$ & $\mathrm{RMSE}=\sqrt{\frac{1}{n} \sum_{i=1}^{n}\left(h_{o}-h_{s}\right)_{i}^{2}}$ & $2.24 \mathrm{~m}$ \\
$\begin{array}{l}\text { Error } \\
\text { Model Efficiency }\end{array}$ & $\mathrm{MEF}=\frac{\sum_{\mathrm{i}=1}^{\mathrm{n}}\left(\mathrm{h}_{\mathrm{o}}-\mathrm{h}_{\mathrm{s}}\right)^{2}}{\sum_{\mathrm{i}=1}^{\mathrm{n}}\left(\mathrm{h}_{\mathrm{o}}-\overline{\mathrm{h}}\right)^{2}}$ & 0.98 \\
$\left(\mathrm{R}^{2}\right)$ & & 0.89
\end{tabular}

$\mathrm{h}_{\mathrm{o}}=$ observed head, $\mathrm{h}_{\mathrm{s}}=$ simulated head, $\mathrm{n}=$ number of values, $\bar{h}=$ observed average $\left(\bar{h}=\sum_{i=1}^{n} \frac{h_{o}}{n}\right)$

Sensitivity analysis: The sensitivity analysis showed that the recharge and transmissivity of the aquifer were most sensitive parameters. The factors of $0.5,0.8,0.9,1.1,1.2,1.3$ and 1.5 were multiplied with the calibrated values of recharge and transmissivity to observe sensitivity of the model against these parameters. The resulted groundwater heads were then compared with the observed heads and root mean squared 
error (RMSE) was calculated for each parameter. It was observed that the minor variation in transmissivity or recharge rate values affected the head impressively. The results of sensitivity showed the non-linear response to recharge and linear response to transmissivity. Abu-el-Shar and Hatamleh (2007) developed MODFLOW model for Azraq basin and reported that model was more sensitive to recharge than specific yield.

Water balance: The annual water balance of the whole study area from year 2003 to 2012 is shown in Figure 7. The water balance describes the volume of water entering, subtraction and net storage in the aquifer system. The water entering parameters are recharge and river leakage, while subtraction parameters are wells and ET.

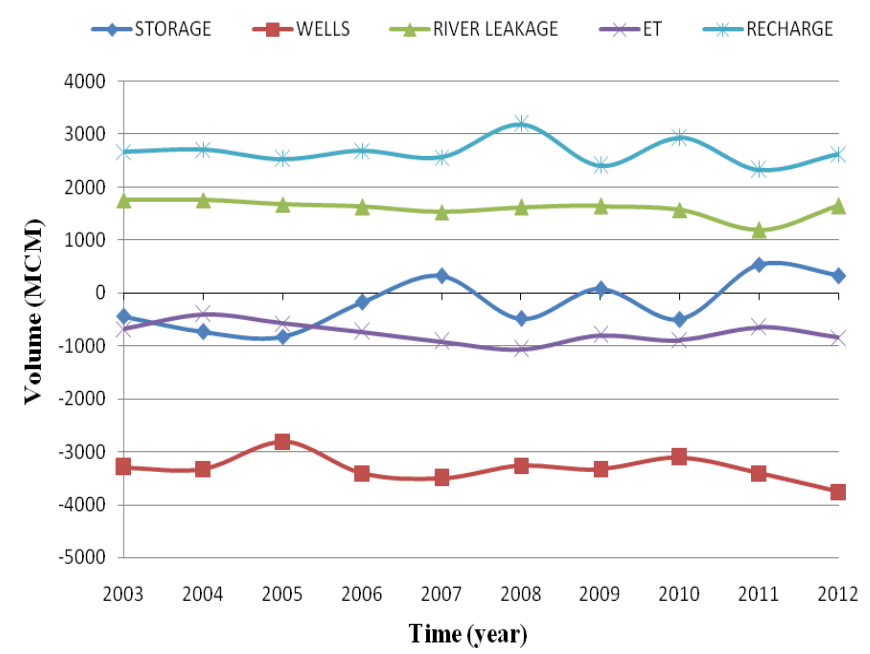

Figure 7. Water balance for years 2003 to 2012.

The positive storage term showed that volume of water extracted from the aquifer was $327 \mathrm{MCM}$ more than the recharge which means crop water demand was fulfilled from aquifer storage and vice versa. The storage in the aquifer in 2003 and 2012 was -444.5 and 326.6 MCM, respectively, clearly indicating the replenishment of aquifer in 2012. Similarly, the volume of water withdrawn through tubewells increased from 3298 to 3759 MCM from years 2003 to 2012, respectively, also showing increased demand of groundwater. Predicted groundwater head: The model predicted results of groundwater head contours and difference in head for all scenarios are given in Figures 8 to 10. The contour lines indicating the spatial variations of the predicted groundwater level and the analysis of contours showed that maximum and minimum groundwater level ranged from 205-145, 205-135 and 205-150m, up to the year 2030 for Scenarios I, II and III, respectively. In first two scenarios, the upward shifting of groundwater head contour and appearance of $135 \mathrm{~m}$ head contour clearly indicating the depletion of groundwater resources if uncheck pumping will continuous. The decrease in groundwater level was more in the middle part of the study area as compare to the lower and upper parts which indicates more groundwater abstraction than the recharge. In the surrounding of Hafizabad city, the average decline in the groundwater level was 2 and $4 \mathrm{~m}$ under Scenario-I and II, respectively. This seems a normal decline after 18 years because of continuous recharge to groundwater from wellestablished irrigation network as shown in Figure 2.

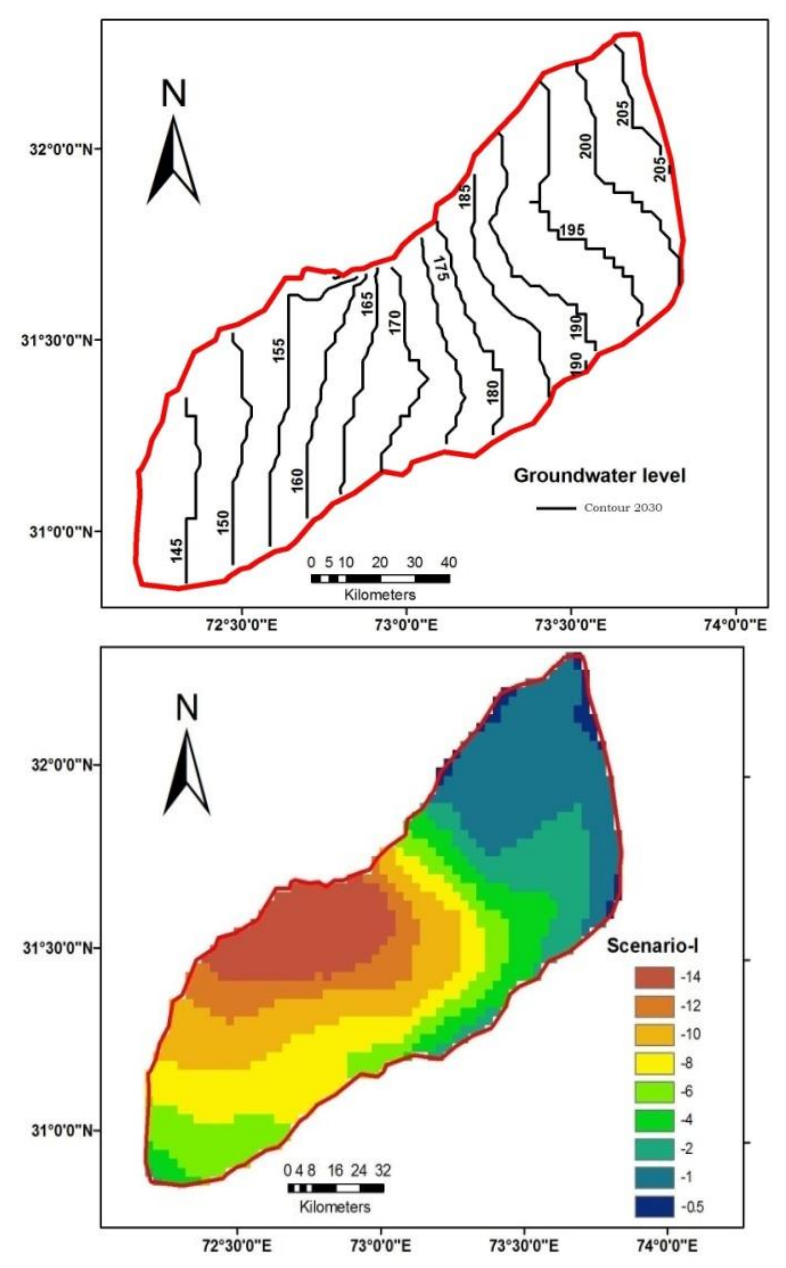

Figure 8. Simulated groundwater head contour and difference in head (Scenario-I).

The highest depletion in groundwater level under Scenario-I and II would up to 14 and $18 \mathrm{~m}$, respectively near Bhawana, located Middle West part of study area, where irrigation is mainly dependent upon groundwater (Figures 8 and 9). As Qureshi et al. (2008) reported that the depletion of groundwater was more pronounced in un-command areas of the Punjab, Pakistan where surface water supplies were constrained and agriculture was heavily dependent on groundwater. Results clearly indicated that the increase in pumping rate is not admissible for the study area because its leads to increase in cost of installation and pumping. This uncheck abstraction of aquifer water also become reason of 
groundwater deterioration by intrusion and upconing (Mekonnen et al., 2016; Asghar, 2014). Qureshi (2012) discussed that the decline in groundwater level would increase the groundwater abstraction cost. The construction cost of a deep electric tubewell (>20 m) was reported as US\$ 5000 as compared to US\$ 1000 for a shallow $(<6 \mathrm{~m})$ tubewell. Obrien et al. (2011) reported that cost of pumping $103 \mathrm{~m}^{3}$ of water was US\$8.61 and US\$18.78 for $31 \mathrm{~m}$ and $91 \mathrm{~m}$ lift, respectively. Basharat and Hashmi (2010) reported that cost of pumping per cubic meter of groundwater increased about 3.5 times because the depth of watertable dropped from 6 to $21 \mathrm{~m}$. Qureshi et al. (2003) calculated that the installation cost of private tubewell in Pakistan was $56800 \mathrm{PKR}$ for the areas where the watertable depth was less than $6 \mathrm{~m}$ and it was $338000 \mathrm{PKR}$ for the areas with more than $24 \mathrm{~m}$ depth. The declining of watertable also leads to upconing and intrusion of salts from the adjacent areas of saline quality groundwater (Khan et al., 2008).
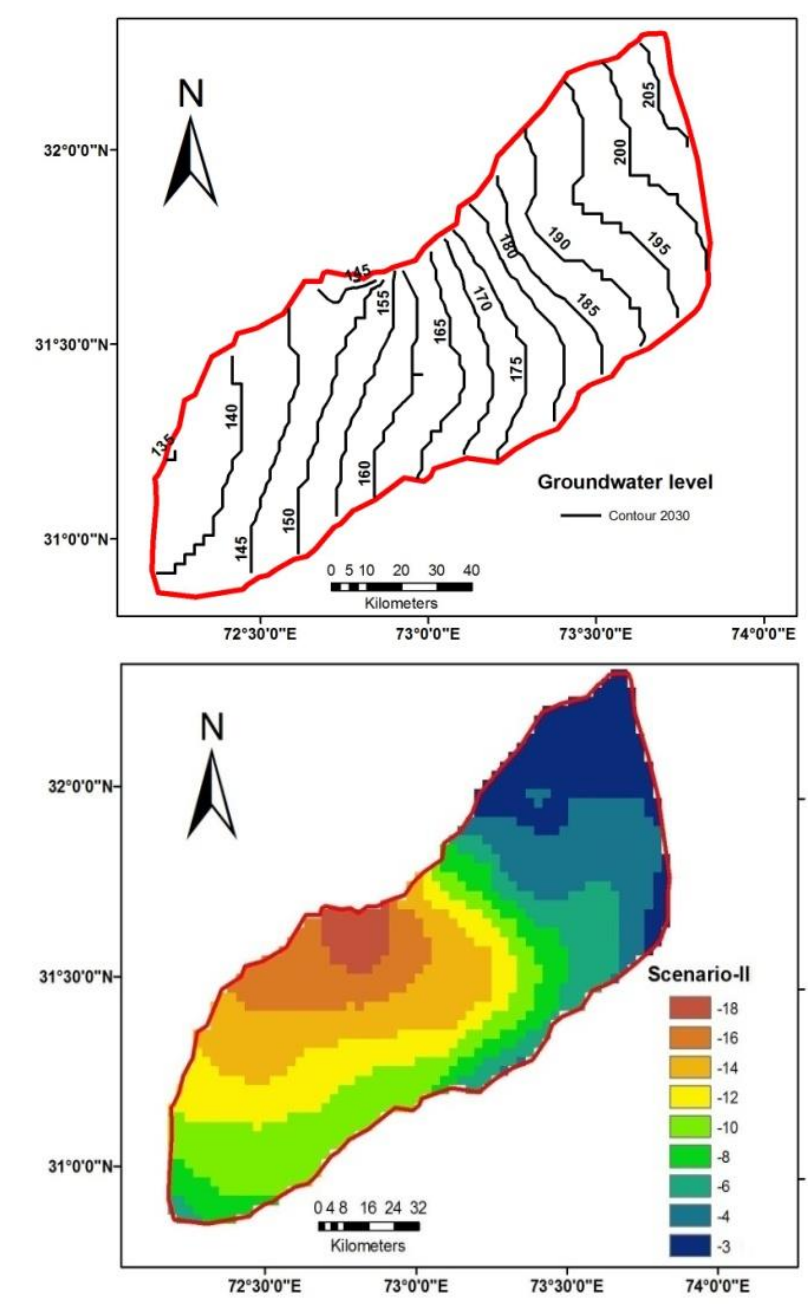

Figure 9. Simulated groundwater head contour and difference in head (Scenario-II).
In Scenario-3, a water management strategy for the study area was proposed for the given conditions in 2012. In upper part of the study area, the results indicated that if pumping is increased by $35 \%$ and recharge is decreased by $35 \%$, there would be a decline of groundwater level by $3-4 \mathrm{~m}$ on the average. The increase in pumping in upper part of study area would not have much adverse effect on groundwater depletion. Because the sustainability in groundwater level is due to high recharge recovery potential available through wide spread irrigation network in that area. In middle part of the study area near Bhawana, if the pumping is decreased and irrigation recharge is increased by the similar levels, there might be a rise of groundwater level by about $2-3 \mathrm{~m}$ on the average (Figure 10), as compared to Scenario-I.
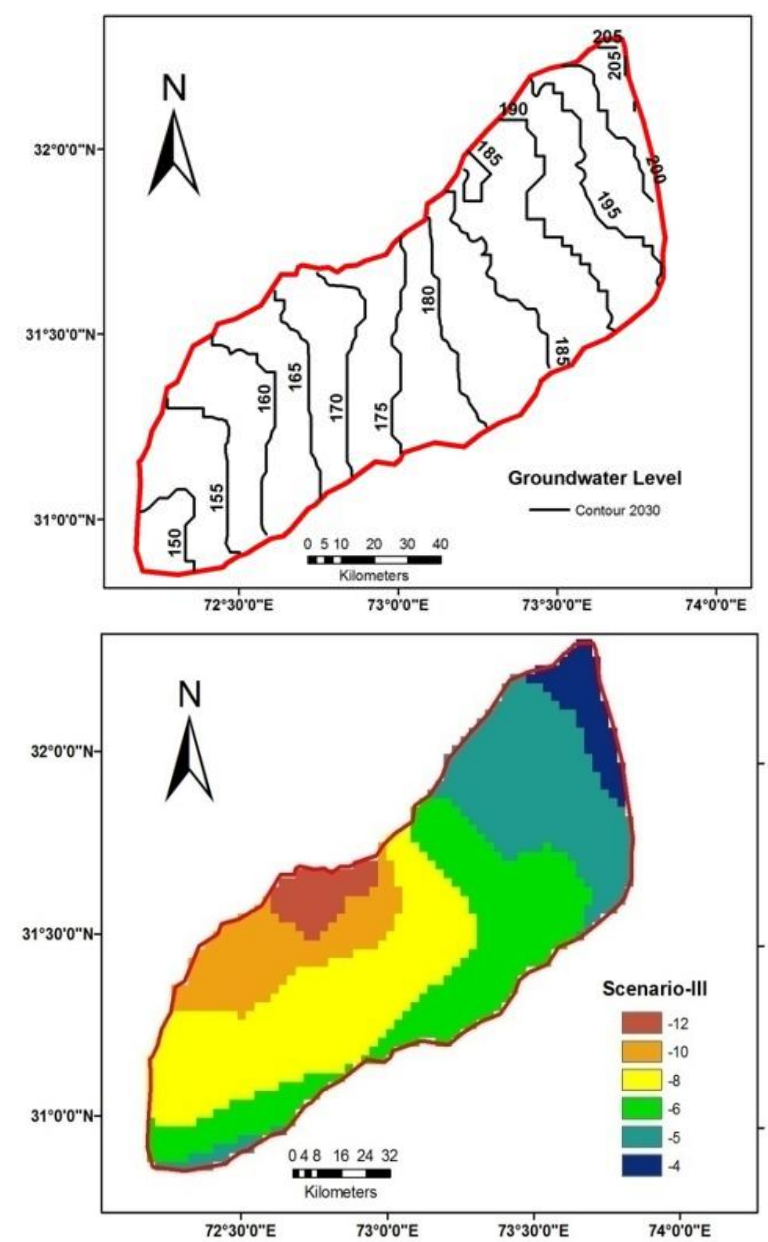

Figure 10. Simulated groundwater head contour and difference in head (Scenario-III).

Thus, reducing recharge and increasing pumping in the upper part of the study area would lead to prevention of water logging situation. While, in the middle part of the study area, decreasing the pumping activity and increasing recharge will help in recovering groundwater aquifer. The adjustment of 
groundwater and surface water among upper and lower part of the study area can provide the sustainable management option for this region. Hence the results of scenario-II revealed that there is a need of hour for a shift in surface irrigation water to reduce groundwater depletion problems. This will also help formers to a way forward for conjunctive surface and groundwater irrigation technology for sustainable water management for this region and to avoid secondary salinization (Mekonnen et al., 2016).

Conclusions: The MODFLOW model was calibrated for a period of 2003-2007 and validated for years 2008-2012 using the measured groundwater level data for regional groundwater management in Punjab province of Pakistan. The surface soil textures are largely fine and moderately medium with good permeability properties. In general the aquifers of study area are unconfined. The intensive pumping of groundwater would rapidly emptying the aquifer. As scenario-I indicated that the groundwater pumping at the current rate would lead towards the groundwater depletion up to $14 \mathrm{~m}$ near Bhawana by the year 2030. Similarly, the increase in the pumping according to the historical trend would also deplete the groundwater up to $18 \mathrm{~m}$. The ScenarioII showed the maximum decline in groundwater level. Thus, the increase in pumping should be avoided as it would deplete the aquifer and decline in groundwater level will make the pumping uneconomical. The adjusted canal and groundwater supplies in Scenario-III would recover the groundwater by 2 $3 \mathrm{~m}$ in the middle part of the study area, gave a good management strategy. This can be achieved by regulating discharge at available irrigation headworks. It is also necessary that the concern department must develop a good understanding among the stake holders of the study area before any variation in water supplies. It is recommended that groundwater should recharge artificially through latest available technique like ASR (Aquifer Storage and Recovery Wells) and supply more surface water to replenish deep water aquifer.

Acknowledgments: The authors acknowledge the financial support from Higher Education Commission (HEC), Pakistan under $\mathrm{PhD}$ Indigenous scholarship program. We are also thankful of WAPDA, Pakistan Meteorology Department and Department of Land and Reclamation, Faisalabad for providing data to accomplish this research.

\section{REFERENCES}

Abdullah, T.T and K. Morteza. 2017. Groundwater modeling by MODFLOW model In Toyserkan aquifer and evaluation of hydrogeological state under present and future conditions. Water Eng. 9:45-60.

Abu-el-Shar, W.A. and R.I. Hatamleh. 2007. Using MODFLOW and MT3D groundwater flow and transport models as a management tool for the Azraq groundwater system. Jordan J. Civil Eng. 1:153-172.

Adane, G.W. 2014. Groundwater Modelling and Optimization of Irrigation water use efficiency to sustain Irrigation in Kobo Valley, Ethiopia. M.Sc. thesis in UNESCO-IHE Institute for Water Education, Delft, the Netherlands; p.89.

Ahmad, M.D. 2002. Estimation of net groundwater use in irrigated river basins using geo-information techniques: a case study in Rechna doab, Pakistan. Ph.D. Thesis, Wageningen University, Netherlands.

Ahmad, N. and G.R. Chaudhary. 1988. Irrigated Agriculture of Pakistan, 61-B/2, Gulberg III, Lahore, Pakistan.

Al-Fatlawi, A.N. 2011. The application of the mathematical model (MODFLOW) to simulate the behavior of groundwater flow in Umm Er Radhuma unconfined aquifer. Euphrates J. Agric. Sci. 3:1-16.

Al-Najar, H. 2011. The integration of FAO-CROPWAT model and GIS techniques for estimating irrigation water requirement and its application in the Gaza strip. Nat. Resour. 2:146-154.

Arshad, M. 2004. Contribution of irrigation conveyance system components to the recharge potential in Rechna Doab under lined and unlined options. $\mathrm{PhD}$ Thesis, Faculty of Agricultural Engineering and Technology, University of Agriculture, Faisalabad-Pakistan.

Arshad, M., A. Shakoor, I. Ahmad and M. Ahmad. 2013. Vertical Electric Sounding Method for Hydraulic Transmissivity Determination in Comparison with Traditional Methods for Groundwater Exploration. Pak. J. Agri. Sci. 50:487-492.

Arshad, M., M.R. Choudhry and N. Ahmed. 2005. Estimation of groundwater recharge from irrigated fields using analytical approach. Int. J. Agric. Biol. 7:285-286.

Asghar, S. 2014. Farming system analysis of irrigated farms in Faisalabad, Pakistan. M.Sc. Thesis Sch. of Environ. Resour. Dev., Asian Inst. Tech., Thailand.

Asoka, A., T. Gleeson, Y. Wada and V. Mishra. 2017. Relative contribution of monsoon precipitation and pumping to changes in groundwater storage in India. Nat. Geosci. 10:109-117.

Basharat, M. and D. Hashmi. 2010. Groundwater management and recharge potential as an alternate to mega surface storages. World Water Day, Pakistan Engineering Congress, Lahore; pp.114-131.

Bhutta, M.N. and L.K. Smedema. 2007. One hundred years of waterlogging and salinity control in the Indus valley, Pakistan: A historical review. Irrig. Drain. 56:581-590.

Carretero, S., J. Rapaglia, H. Bokuniewicz and E. Kruse. 2013. Impact of sea-level rise on saltwater intrusion length into the coastal aquifer, Partido de La Costa, Argentina. Continental Shelf Res. 62:62-70.

Cavero, J., I. Farre, P. Debaeke and J.M. Faci. 2000. Simulation of Maize Yield under Water Stress with the 
EPIC phase and CROPWAT Models. Agron. J. 92:679690.

Chiang, W.H and W. Kinzelbach. 1998. Processing Modflow: A simulation system for modeling groundwater flow and pollution. User's manual; U.S. Department of the Interior, U.S. Geol. Surv; pp.1-20.

Cliffen, S. and G. Wedden. 2009. Best practices for assessing nextmap Europe data quality and accuracy. ASPRS/MAPPS 2009 Fall Conference, San Antonio, Texas; pp.1-12.

CSIRO. 2003. Investigation Conjunctive Water management options using a dynamic surface-groundwater modeling approach: A case study of Rechna Doab. Commonwealth Scientific and Industrial Research Organization (CSIRO), Land and Water Dept. Tech. Rep. 35/03, pp.47-52.

Doherty, J., L. Brebber and P. Whyte. 1994. PEST- Modelindependent parameter estimation. User's manual. Watermark Computing, Australia; p.122.

Durand, V., V. Léonardi, G.D. Marsily and P. Lachassagne. 2017. Quantification of the specific yield in a two-layer hard-rock aquifer model. J. Hydrol. 551:328-339.

FAO. 1998. Crop evapotranspiration: Guidelines for computing crop water requirements. In: R.G. Allen, L.S. Pereira, D. Raes and M. Smith (eds.), Irrigation and Drainage Paper 56. Food and Agriculture Organization, Rome, Italy; p. 290.

Galitskaya, I.V., K.R. Mohan, A.K. Krishna, G.I. Batrak, O.N. Eremina, V.S. Putilina and T.I. Yuganova. 2017. Assessment of soil and groundwater contamination by heavy metals and metalloids in Russian and Indian megacities. Procedia Earth Planet Sci. 17:674-681.

Gebreyohannes, T., F.D. Smedt, K. Walraevens, S. Gebresilassie, A. Hussien, M. Hagos, K. Amare, J. Deckers and K. Gebrehiwot. 2017. Regional groundwater flow modeling of the Geba basin, northern Ethiopia. Hydrogeol. J. 25:639-655.

Ghani, M.W., M. Arshad, A. Shabbir, A. Shakoor, N. Mehmood and I. Ahmad. 2013. Investigation of potential water harvesting sites at Potohar using modeling approach. Pak. J. Agri. Sci. 50:723-729.

Gibb, J.P, M.J. Barcelona, J.D. Ritchey and M.H. LeFaivre. 1984. Effective porosity of geologic materials. Ground Water Section, State Water Surv. Div. Rep. 351; pp.1-40.

Gohari, A.A. 2013. Simulation of peanut (Arachis hypogaea L.) with CROPWAT model in irrigation condition and rainfed. Sci. Agric. 2:54-59.

Hagos M.A. 2010 Groundwater flow modeling assisted by GIS and RS techniques (Raya valley- Ethiopia). M.Sc. Thesis IntlInst. Geo-info. Sci. Earth Obs. Enschede, the Netherlands.

Iyanda, R.A., G. Pranuthi, S.K. Dubey and S.K. Tripathi. 2014. Use of DSSAT ceres maize model as a tool of identifying potential zones for maize production in Nigeria. Int. J. Agric. Policy Res. 2:069-075.

Jehangir, W.A., A.S. Qureshi and N. Ali. 2002. Conjunctive water management in the Rechna Doab: An overview of resources and issues. Working Paper 48. Int. Water Manage. Inst., Lahore, Pakistan 13:1-65.

Kaleem-Ullah, M., Z. Habib and S. Muhammad. 2001. Spatial distribution of reference and potential evapotranspiration across the Indus Basin Irrigation Systems. Int. Water Manage. Inst., Lahore, Pakistan 24:1-62.

Kambale, J.B., D.K. Singh and A. Sarangi. 2017. Impact of climate change on groundwater recharge in a semi-arid region of northern India. Appl. Ecol. Environ. Res. 15:335-362.

Khan, S., T. Rana, H.F. Gabriel and M.K. Ullah, 2008. Hydrogeologic assessment of escalating groundwater exploitation in the Indus Basin, Pakistan. Hydrogeo. J. 16:1635-1654.

Kori, S.M., A.L. Qureshi, B.K. Lashari and N.A Memon. 2013. Optimum strategies of groundwater pumping regime under scavanger tubewells in lower Indus basin, Sindh, Pakistan. Inter. Water Tech. J. 3:138-145.

Korzeniowska, K. 2012. Modelling of water surface topography on the Digital Elevation Models using LiDAR data. Multidisciplinary Research on Geographical Information in Europe and Beyond. Proceedings of the AGILE'2012 International Conference on Geographic Information Science, Avignon; pp.333-335.

Lalehzari, R., S.H. Tabatabaei and M. Kholghi. 2010. Hydrodynamic coefficients estimation and aquifer simulation using PMWIN model. $14^{\text {th }}$ Int. Water Tech.Conf., Cairo, Egypt; pp.925-939.

McWhorter, D.B. and D.K. Sunada. 1977. Ground-Water Hydrology and Hydraulics. Water Resources Publications, Danver Co., Colorado, United States.

Mekonnen D., A. Siddiqi and C. Ringler. 2016. Drivers of groundwater use and technical efficiency of groundwater, canal water, and conjunctive use in Pakistan's Indus basin irrigation system. Int. J. Water Resour. Dev. 32:459-476.

Moeck, C., A. Affolter, D. Radny, A. Auckenthaler, P. Huggenberger and M. Schirmer. 2017. Improved water resource management using three dimensional groundwater modelling for a highly complex environmental. InEGU Gen. Assembly Conf. Abstr. 19:19056.

Moon, C., N. Kim, J. Lee and M. Sophocleous. 2010. Assessing distributed groundwater recharge rate using integrated surface water groundwater modeling: application to Mihocheon Watershed, South Korea. Hydrol. J. 18:1253-1264. 
Moriasi, D.N., J.G. Arnold, M.W. Van Liew, R.L. Bingner, R.D. Harmel and T.L. Veith. 2007. Model evaluation guidelines for systematic quantification of accuracy in watershed simulations. Am. Soc. Agric. Biol. Eng. 50:885-900.

Nazeer, M. 2009. Simulation of maize crop under irrigated and rainfed conditions with CROPWAT model. ARPN J. Agric. Biol. Sci. 4:68-73.

Obrien, D.M., T.J. Dumler and D.H. Rogers. 2011. Irrigation capital requirements and energy costs. Kansas State University Farm Manage. Guide, MF 836:1-4.

PES. 2009. Pakistan Economic Survey 2008-09, Agriculture, Table 107. Federal Bureau of Statistics, Statistics Division, Ministry of economic affairs and statistics, Govt. of Pakistan, Islamabad, Pakistan; pp.171-172.

PES. 2011. Pakistan Economic Survey 2010-11, Agriculture, Table 64 "Area Irrigated by Different Sources". Federal Bureau of Statistics, Statistics Division, Ministry of economic affairs and statistics, Govt. of Pakistan, Islamabad, Pakistan; pp.113-115.

Qureshi, A.S. 2012. Groundwater management in Pakistan: The question of balance. Centenary Celebration (19122012), Pakistan Engineering Congress, Lahore; pp.207217.

Qureshi, A.S., P.G. McCornick, A. Sarwar and B.R. Sharma. 2010. Challenges and prospects of sustainable groundwater management in the Indus Basin, Pakistan. Water Resour. Manage. 24:1551-1569.

Qureshi, A.S., P.G. McCornick, M. Qadir and Z. Aslam. 2008. Managing salinity and waterlogging in the Indus Basin of Pakistan. Agric. Water Manage. 95:1-10.

Qureshi, A.S., T. Shah and M. Akhtar. 2003. The groundwater economy of Pakistan. Working Paper 64. Int. Water Manage. Inst. (IWMI), Lahore, Pakistan; pp.1-31.

Rahmawati, N., J.F. Vuillaume and I.L.S. Purnama. 2013. Salt intrusion in Coastal and Lowland areas of Semarang City. J. Hydrol. 494:146-159.
Schoups, G., C.L. Addams and S.M. Gorelick. 2005. Multiobjective calibration of a surface water-groundwater flow model in an irrigated agricultural region: Yaqui Valley, Sonora, Mexico. Hydrol. Earth Syst. Sci. 9:549-568.

Shabbir, A., M. Arshad, A. Bakhsh, M. Usman, A. Shakoor, I. Ahmad and A. Ahmad. 2012. Apparent and real water productivity for cotton-wheat zone of Punjab, Pakistan. Pak. J. Agri. Sci. 49:357-363.

Shah, T. 2014. Groundwater governance and irrigated agriculture. Tech. background papers No. 19. Global Water Partnership Technical Committee (TEC); pp.1-69.

Shakoor, A., M. Arshad, A. Bakhsh and R. Ahmad. 2015. GIS based assessment and delineation of groundwater quality zones and its impact on agricultural productivity. Pak. J. Agri. Sci. 52:837-843.

Shakoor, A., M. Arshad, A.R. Tariq and I. Ahmad. 2012. Evaluating the role of bentonite embedment in controlling infiltration and improve root zone water distribution in coarse soil. Pak. J. Agri. Sci. 49:375-380.

WAPDA. 1978. Hydrogeological Data of Rechna Doab. Volume-I, Publication No. 25. Water and Power Development Authority, Project Planning Organization (N.Z), 27-E/I Gulberg III, Lahore, Pakistan.

Watto, M.A and A.W. Mugera. 2016. Groundwater depletion in the Indus Plains of Pakistan: Imperatives, repercussions and management issues. Int. J. River Basin Manage. 14:447-458.

Wilkinson, J.M. 2012. The application and revision of a new relationship to calculate effective porosity from specific capacity on a well database in the Pacific Northwest. Hydrol. Res. Lett. 6:98-103.

Zailin, H., S. Feng, S. Kang, X. Mao and F. Wang. 2011. Numerically modelling groundwater in an arid area with ANN-generated dynamic boundary conditions. Hydrol. Process. 25:705-713. 